\title{
MOISTURE CONDITIONS DURING THE VEGETATION SEASON IN YEARS 1954-1995 IN ŁÓDŹ
}

\author{
Elżbieta Musiał' , Edward Gąsiorek \\ 1 Department of Mathematics, Wrocław University of Environmental and Life Sciences, Grunwaldzka Str. 53, \\ 50-375 Wrocław, Poland, e-mail: elzbieta.musial@up.wroc.pl
}

Received: 2015.08.31

Accepted: 2015.10.06

Published: 2015.11.10

\begin{abstract}
The standardized precipitation index (SPI), standardized reference evapotranspiration index (SEI) and standardized climatic water balance index (SCWBI) were used to analyze moisture conditions in the vegetation seasons of 1954-1995 in Łódź. SPI and SEI were calculated on the assumption that empirical monthly precipitation sums and monthly sums of reference evapotraspiration are gamma distributed. Because monthly sums of climatic water balance are normally distributed, they required standardization to SCWBI. The aim of study was to compare those three indexes (SPI SEI and SCWBI) for years 1954-1995 in Łódź.
\end{abstract}

Keywords: reference evapotranspiration, precipitation, climatic water balance.

\section{INTRODUCTION}

Climatic water balance (SCWBI) is an indicator defining environmental moisture conditions, otherwise actual water availability, with the use of meteorological data. Monitoring drought conditions in Poland has been in focus for years and the climatic water balance index has already been used by Rojek [1994], Farat et al. [1995], Kanecka-Geszke et al. [2007], Mizak et al. [2011], Wibig [2012] and Radzka 2014). Łabędzki and Bąk [2004] calculated the standardized climatic water balance with the use of reference evapotranspiration. The analysis of SCWBI and moisture conditions for WrocławSwojec region was already presented in our previous article [Gąsiorek et al. 2014]. The aim of this study was to compare the following three indexes: standardized precipitation index (SPI), standardized evapotranspiration index (SEI) and standardized climatic water balance index (SCWBI) for the vegetation seasons in 1954-1995 in Łódź.

\section{METHODS AND MATERIALS}

With the definition of reference crop as an actively growing and well watered green grass surface with a height of $0.12 \mathrm{~m}$, having a surface resistance of $70 \mathrm{~s} \cdot \mathrm{m}^{-1}$ and an albedo of 0.23 , reference evapotranspiration was calculated from the Penman-Monteith equation with modification by Allen [Allen et al. 1994a, 1994b] as:

$$
E T_{0}=\frac{\Delta\left(R_{n}-G\right)+\rho c_{p} d / r_{a}}{\Delta+\gamma\left(1+\frac{r_{c}}{r_{a}}\right)} \cdot \frac{n}{28.34}
$$

The consistency of empirical distribution of monthly sums of evapotranspiration, precipitation and climatic water balance in the vegetation period for years 1954-1995 in Łódź was verified with the use of $\chi^{2}$ test.

Then the estimators calculated by Thom [Thom H.C.S., 1958] with the maximum likelihood method were used as a scale and shape estimators of the gamma distribution. The mean sample and variance sample were used as the estimators of normal distribution parameters. Having fitted theoretical distributions to the empirical data, the SEI and SPI indices were estimated with the use of procedure calculating quantiles of standard normal distribution [Abramowitz et al. 1965].

Because monthly sums of climatic water balance are normally distributed, the standard- 
ized climatic water balance index was calculated by the standardization of random variable CWB [Łabędzki et al. 2004]. A detailed description of the above mentioned methodology can be found in our previous publications [Gąsiorek et al. 2012; 2014].

\section{RESULTS AND DISCUSSION}

The results of verification of the consistency hypothesis of gamma distribution for monthly precipitation sums and reference evapotranspiration, and the consistency hypothesis of normal distribution for monthly sums of CWB in the vegetation period in years 1954-1995 in Łódź, with the use of $\chi^{2}$ test, are shown in Table 1.

The values of indexes SPI, SEI and SCWBI, calculated for the following months of the vegetation season in years 1954-1995, are shown in Figure $1(a-f)$.

The analysis of relations between SPI, SEI and SCWBI indexes was shown by the example of vegetation season in 1981. For June 1981, the values were as follows: $\mathrm{SPI}=1.04$; $\mathrm{SEI}=-1.08$, $\mathrm{SCWBI}=1.08$. July was characterized by the indexes: $\mathrm{SPI}=0,62 ; \mathrm{SEI}=-0.58, \mathrm{SCWBI}=0.54$.
The August values were: $\mathrm{SPI}=0.57 .04 ; \mathrm{SEI}=$ -0.71 ; SCWBI $=0.52$.

The detailed analysis of Figures $1 \mathrm{a}$ to $1 \mathrm{f}$ and the data from Table 2 led to the classification shown in Table 3. The relations seen in the figures point at the following rule: an extremely dry month according to SPI (SP $\mathrm{I} \leq-2,0$ ) has the SEI value $\geq 2$. Likewise, a wet month $(0,5 \leq$ SPI $<1,50)$ is characterized by the SEI value: $-1.50<$ SEI $\leq-0,50$.

The inverse relation between SPI and SEI in evaluation of moisture conditions confirms that increasing precipitation diminishes the ability of atmosphere, lying over the evaporating surface, to absorb water vapour. Such an ability is assessed by the reference evapotranspiration.

The above-mentioned relations are biased with random error and the consistency evaluation, shown in Table 4, confirms it. The analysis of figures also revealed that the SPI and SCWBI values for the following months of the vegetation season are similar, thus the assessment of moisture conditions with precipitation sums gives nearly identical classification as in the case of climatic water balance, provided the following meteorological data are taken into account: air moisture

Table 1. Verification of the consistency hypothesis of gamma distribution for monthly precipitation sums and reference evapotranspiration and the consistency hypothesis of normal distribution for monthly sums of CWB in the vegetation season in years 1954-1995 for Łódź

\begin{tabular}{|c|c|c|c|c|c|c|c|c|c|}
\hline \multirow{3}{*}{ Month } & \multicolumn{3}{|c|}{ Inference evapotranspiration } & \multicolumn{3}{|c|}{ Precipitation } & \multicolumn{3}{|c|}{ Climatic water balance } \\
\hline & \multirow{2}{*}{$p$-value } & \multicolumn{2}{|c|}{ parameter } & \multirow{2}{*}{$p$-value } & \multicolumn{2}{|c|}{ parameter } & \multirow{2}{*}{ p-value } & \multicolumn{2}{|c|}{ parameter } \\
\hline & & shape- $\alpha$ & scale- $\beta$ & & shape- $\alpha$ & scale- $\beta$ & & $\mu$ & $\sigma$ \\
\hline April & 0.19 & & & 0.68 & & & 0.37 & & \\
\hline May & 0.04 & & & 0.58 & & & 0.71 & & \\
\hline June & 0.05 & & & 0.81 & & & 0.55 & & \\
\hline July & 0.09 & 30.53 & 2.37 & 0.11 & 3.30 & 25.53 & 0.17 & 11.80 & 55.87 \\
\hline August & 0.61 & 52.31 & 1.18 & 0.85 & 4.0 & 16.91 & 0.08 & 5.87 & 40.74 \\
\hline September & 0.84 & 33.67 & 1.12 & 0.05 & 2.82 & 16.83 & 0.19 & 9.74 & 29.11 \\
\hline
\end{tabular}

Table 2. Classification of precipitation conditions according to the standardized precipitation index (SPI) and corresponding probabilities [McKee et al. 1993, 1995; Łabędzki 2006a]

\begin{tabular}{|l|l|l|}
\hline \multicolumn{1}{|c|}{ SPI } & \multicolumn{1}{c|}{ Period } & \multicolumn{1}{c|}{ Probabilities } \\
\hline $\mathrm{SPI} \leq-2,0$ & extremely dry & $\mathrm{P}(\mathrm{SPI} \leq-2)=0,02$ \\
\hline$-2,00<\mathrm{SPI} \leq-1,50$ & very dry & $\mathrm{P}(-2<\mathrm{SPI} \leq-1,5)=0,04$ \\
\hline$-1.50<\mathrm{SPI} \leq-0,50$ & dry & $\mathrm{P}(-1,5<\mathrm{SPI} \leq-0,5)=0,25$ \\
\hline$-0,5<\mathrm{SPI}<0,5$ & normal & $\mathrm{P}(-0,5<\mathrm{SPI}<0,5)=0,38$ \\
\hline $0,5 \leq \mathrm{SPI}<1,5$ & wet & $\mathrm{P}(0,5 \leq \mathrm{SPI}<1,5)=0,25$ \\
\hline $1,5 \leq \mathrm{SPI}<2$ & very wet & $\mathrm{P}(1,5 \leq \mathrm{SPI}<2)=0,04$ \\
\hline $\mathrm{SPI} \geq 2$ & extremely wet & $\mathrm{P}(\mathrm{SPI} \geq 2)=0,02$ \\
\hline
\end{tabular}

Table 3. Classification of precipitation conditions according to the standardized reference evapotranspiration index (SEI) and corresponding probabilities

\begin{tabular}{|l|l|l|}
\hline \multicolumn{1}{|c|}{ SEI } & \multicolumn{1}{c|}{ Period } & \multicolumn{1}{c|}{ Probabilities } \\
\hline SEI $\leq-2,0$ & extremely wet & $\mathrm{P}(\mathrm{SEI} \leq-2)=0,02$ \\
\hline$-2,00<$ SEI $\leq-1,50$ & very wet & $\mathrm{P}(-2<\mathrm{SEI} \leq-1,5)=0,04$ \\
\hline$-1.50<$ SEI $\leq-0,50$ & wet & $\mathrm{P}(-1,5<$ SEI $\leq-0,5)=0,25$ \\
\hline$-0,5<$ SEI $<0,5$ & normal & $\mathrm{P}(-0,5<$ SEI $<0,5)=0,38$ \\
\hline $0,5 \leq$ SEI $<1,5$ & dry & $\mathrm{P}(0,5 \leq \mathrm{SEI}<1,5)=0,25$ \\
\hline $1,5 \leq$ SEI $<2$ & very dry & $\mathrm{P}(1,5 \leq \mathrm{SEI}<2)=0,04$ \\
\hline SEI $\geq 2$ & extremely dry & $\mathrm{P}(\mathrm{SEI} \geq 2)=0,02$ \\
\hline
\end{tabular}


Table 4. Consistency assesment of coefficients SPI, SEI and SCWBI

\begin{tabular}{|c|c|c|c|c|c|c|}
\hline \multirow{2}{*}{ Month } & \multicolumn{2}{|c|}{ Percent of identical classification } & \multicolumn{3}{c|}{ Percent of identical or neighbor classification } \\
\cline { 2 - 7 } & SPI-SEI & SEI-SCWBI & SPI-SCWBI & SPI-SEI & SEI-SCWBI & SPI-SCWBI \\
\hline April & $35 \%$ & $49 \%$ & $70 \%$ & $74 \%$ & $77 \%$ & $98 \%$ \\
\hline May & $37 \%$ & $44 \%$ & $74 \%$ & $81 \%$ & $88 \%$ & $93 \%$ \\
\hline June & $37 \%$ & $49 \%$ & $79 \%$ & $77 \%$ & $81 \%$ & $93 \%$ \\
\hline July & $40 \%$ & $51 \%$ & $70 \%$ & $79 \%$ & $86 \%$ & $93 \%$ \\
\hline August & $42 \%$ & $44 \%$ & $77 \%$ & $84 \%$ & $86 \%$ & $95 \%$ \\
\hline September & $44 \%$ & $49 \%$ & $72 \%$ & $74 \%$ & $79 \%$ & $93 \%$ \\
\hline
\end{tabular}

Table 5. Precipitation conditions classification according to SPI and SCWBI in Łódź in June in the years 1954-1995

\begin{tabular}{|c|c|c|c|c|c|}
\hline Year & SPI & Classification & SCWBI & Classification & $\begin{array}{l}1 \text { - the same classification } \\
0-\text { neighbor classification }\end{array}$ \\
\hline 1954 & 0.3 & normal & -0.1 & normal & 1 \\
\hline 1955 & -0.5 & normal & -0.5 & normal & 1 \\
\hline 1956 & -0.1 & normal & -0.2 & normal & 1 \\
\hline 1957 & 0.3 & normal & -0.2 & normal & 1 \\
\hline 1958 & 0.1 & normal & 0.1 & normal & 1 \\
\hline 1959 & 0.5 & normal & 0.1 & normal & 1 \\
\hline 1960 & 0.5 & normal & 0.4 & normal & 1 \\
\hline 1961 & -1.2 & dry & -1.1 & dry & 1 \\
\hline 1962 & -0.8 & dry & -0.7 & dry & 1 \\
\hline 1963 & -1.0 & dry & -1.0 & dry & 1 \\
\hline 1964 & 1.0 & wet & 0.5 & wet & 1 \\
\hline 1965 & -0.5 & dry & -0.5 & dry & 1 \\
\hline 1966 & -0.5 & normal & -0.7 & dry & 0 \\
\hline 1967 & 0.5 & wet & 0.3 & normal & 0 \\
\hline 1968 & 1.9 & very wet & 1.7 & very wet & 1 \\
\hline 1969 & 1.8 & very wet & 1.6 & very wet & 1 \\
\hline 1970 & -0.9 & dry & -0.9 & dry & 1 \\
\hline 1971 & 1.2 & wet & 1.3 & wet & 1 \\
\hline 1972 & 0.4 & normal & 0.4 & normal & 1 \\
\hline 1973 & -0.4 & normal & -0.4 & normal & 1 \\
\hline 1974 & -0.1 & normal & 0.1 & normal & 1 \\
\hline 1975 & -0.4 & normal & -0.5 & normal & 1 \\
\hline 1976 & -1.2 & dry & -1.0 & dry & 1 \\
\hline 1977 & -0.2 & normal & -0.5 & normal & 1 \\
\hline 1978 & 0.1 & normal & -0.1 & normal & 1 \\
\hline 1979 & -0.1 & normal & -0.5 & dry & 0 \\
\hline 1980 & 3.0 & extremely wet & 3.9 & extremely wet & 1 \\
\hline 1981 & 1.0 & wet & 1.1 & wet & 1 \\
\hline 1982 & 1.0 & wet & 0.8 & wet & 1 \\
\hline 1983 & -2.1 & extremely dry & -1.5 & dry & 0 \\
\hline 1984 & -0.4 & normal & -0.1 & normal & 1 \\
\hline 1985 & 0.2 & normal & 0.5 & wet & 0 \\
\hline 1986 & -0.9 & dry & -0.8 & dry & 1 \\
\hline 1987 & 0.9 & wet & 1.2 & wet & 1 \\
\hline 1988 & 0.1 & normal & 0.1 & normal & 1 \\
\hline 1989 & 0.5 & normal & 0.5 & wet & 0 \\
\hline 1990 & -0.7 & dry & -0.6 & dry & 1 \\
\hline 1991 & 0.6 & wet & 0.5 & wet & 1 \\
\hline 1992 & -1.6 & extremely dry & -1.5 & dry & 0 \\
\hline 1993 & -0.1 & normal & -0.1 & normal & 1 \\
\hline 1994 & -2.1 & extremely dry & -1.5 & dry & 0 \\
\hline 1995 & -0.3 & normal & -0.3 & normal & 1 \\
\hline
\end{tabular}


a) 4.0

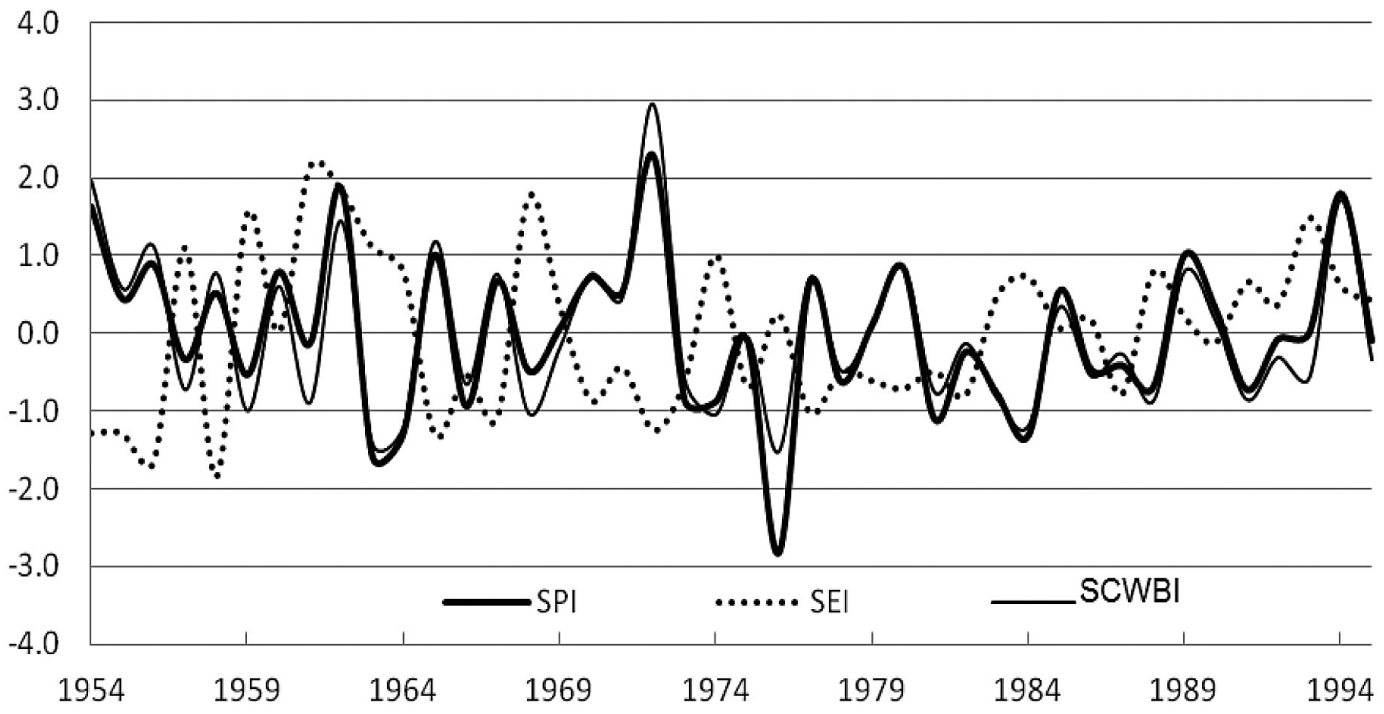

b)

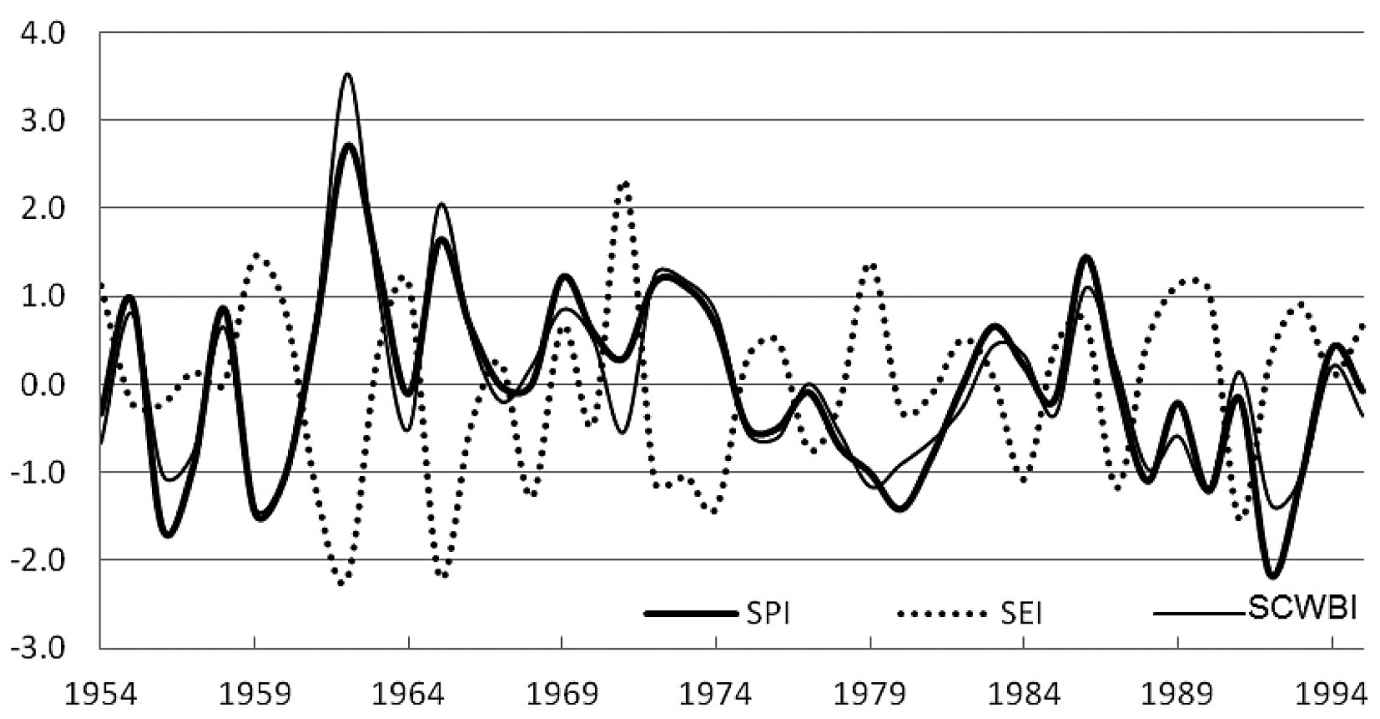

c) 5.0

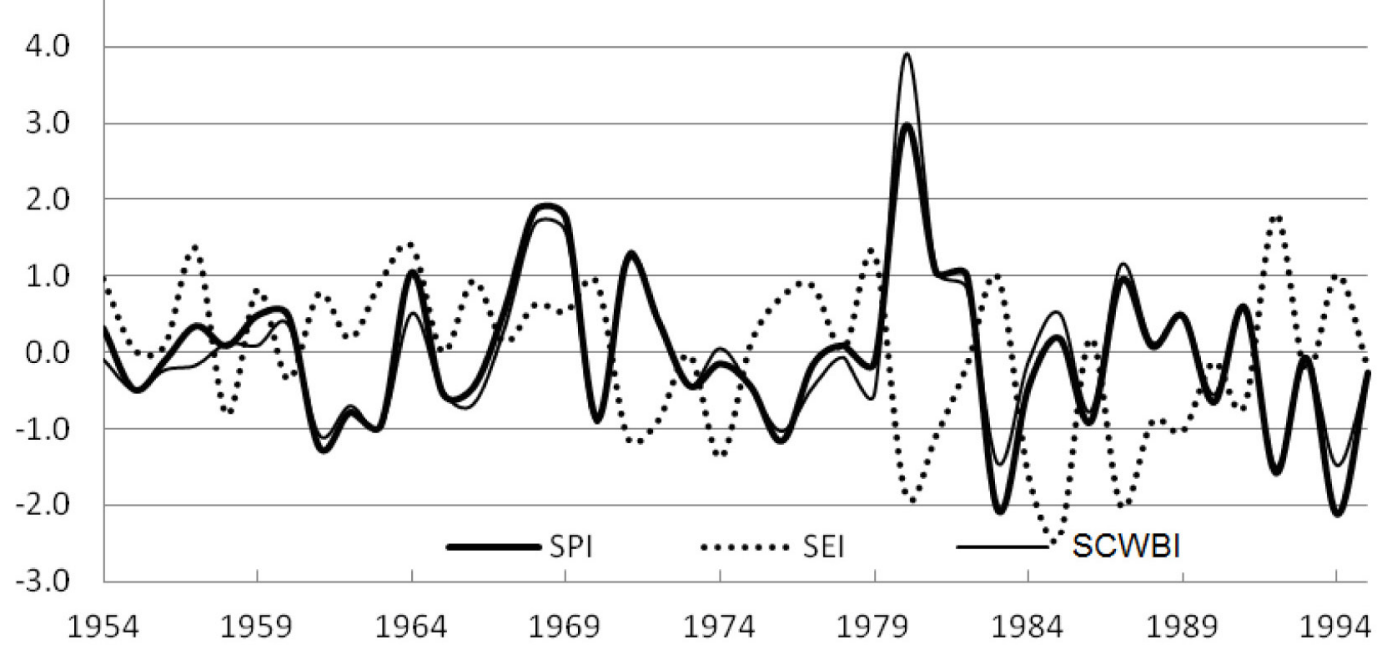

Figure 1. Comparison of SPI, SEI and SCWBI for Łódź (1954-1995) in months:

a) April, b) May, c) June, d) July, e) August, f).September 
d) 3.0

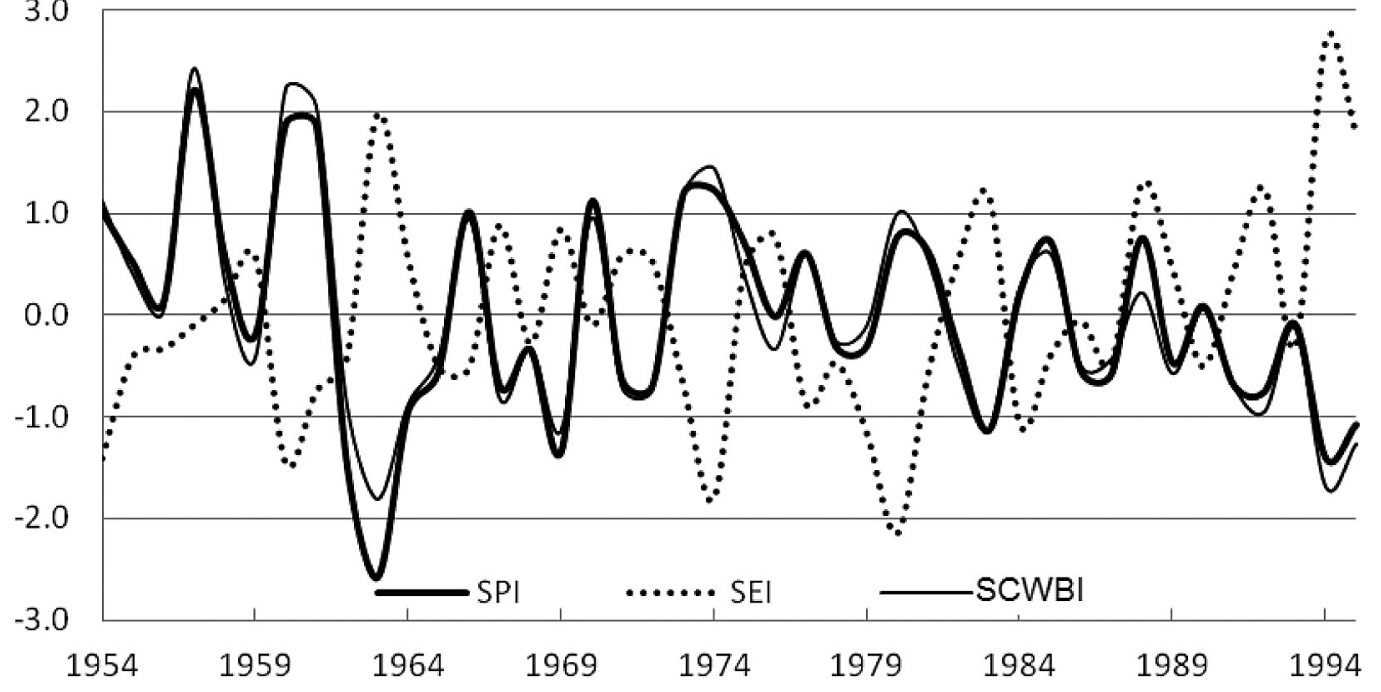

e) 4.0

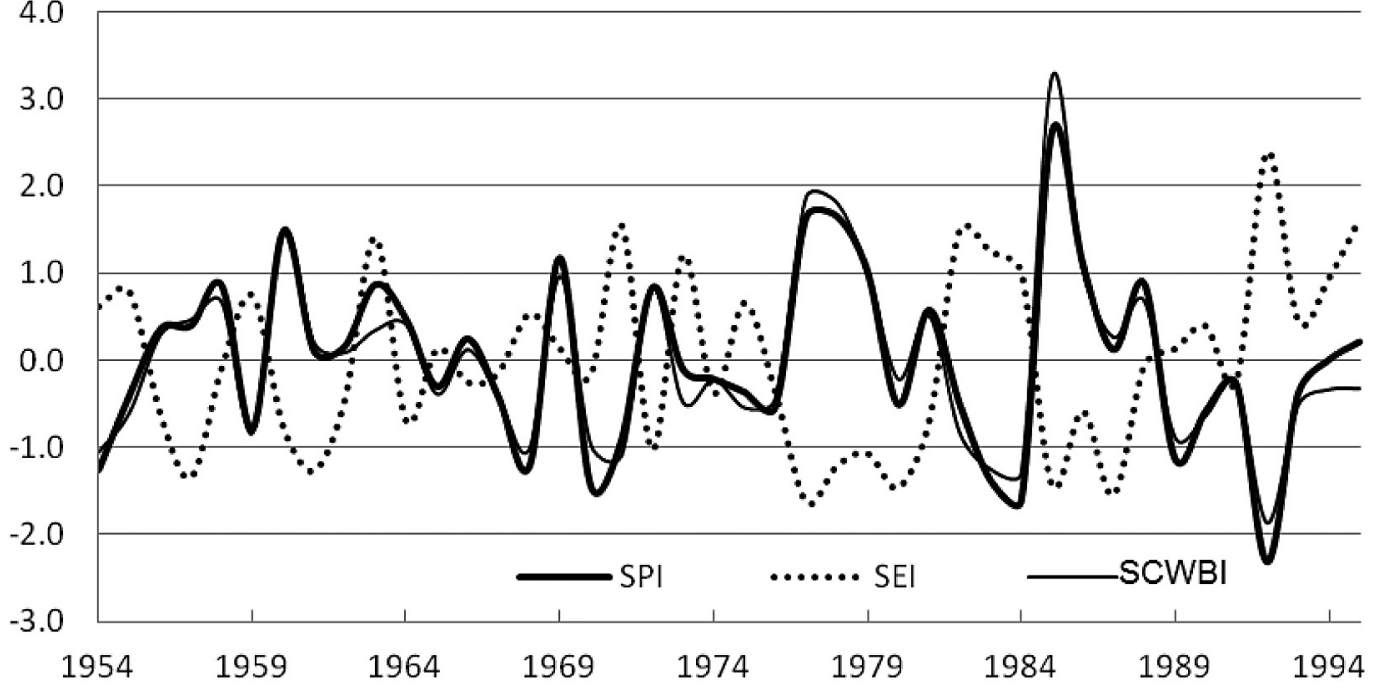

f) 3.0

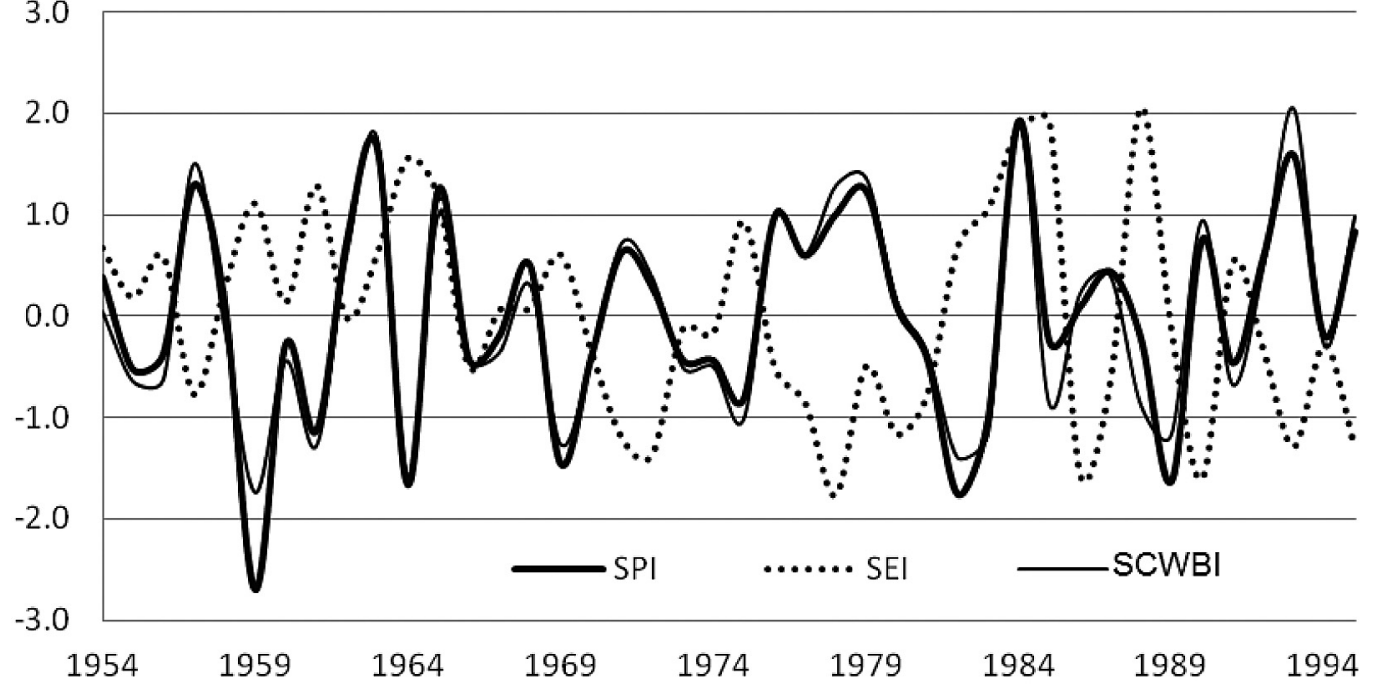

Figure 1. Comparison of SPI, SEI and SCWBI for Łódź (1954-1995) in months:

a) April, b) May, c) June, d) July, e) August, f).September 
Table 6. Correlation coefficient between SPI, SEI and SCWBI

\begin{tabular}{|c|c|c|c|}
\hline \multirow{2}{*}{ Month } & \multicolumn{3}{|c|}{ Correlation coefficient } \\
\cline { 2 - 4 } & SPI-SEI & SEI-SCWBI & SPI-SCWBI \\
\hline April & -0.33 & -0.55 & 0.94 \\
\hline May & -0.47 & -0.68 & 0.95 \\
\hline June & -0.42 & -0.57 & 0.96 \\
\hline July & -0.63 & -0.72 & 0.97 \\
\hline August & -0.61 & -0.71 & 0.97 \\
\hline September & -0.37 & -0.49 & 0.96 \\
\hline
\end{tabular}

deficit, actual sun exposure, air temperature and wind speed.

The assessment of SPI and SEI consistency in identification of monthly periods from extremely dry to extremely wet with the use of proposed methods was put into Table 4. The assessment of SPI, SEI and SCWBI consistency was performed by the identification of percentage of identical classifications, as well as percentage of identical and neighbouring classifications.

The analysis of data from Table 4 reveals that in the analyzed period 1954-1995 in Łódź, the consistency between SPI and SCWBI values fluctuated from $70 \%$ in April to $79 \%$ in June. When the neighbouring classifications were taken into account, this consistency has risen to the values from $93 \%$ in April to $98 \%$ in June. In order to prove the similarity of SPI and SCWBI values in the analyzed months of vegetation season, the exemplary classification for June was shown in Table 5.

The consistency of identification in June in years 1954-1995 has reached 79\%. The relations among SPI, SEI and SCWBI are best described by the values of correlation coefficient between these indexes, put into Table 6 .

The values of correlation coefficient confirm the relations shown in figures 1a to 1f. Relations between SEI and SPI, as well as between SEI and SCWBI, are negative. Thus, the elevation of one index is accompanied of the decrease of the other. Contrarily, the relation between SPI and SCWBI is positive and nearing $100 \%$, which proves the very close similarity of the values of both indexes.

\section{CONCLUSIONS}

1. Monthly sums of reference evapotranspiration and precipitation during the vegetation season in years 1954-1995 in Łódź are gamma distributed. Monthly sums of climatic water balance in the analyzed period are normally distributed.

2. Standardized precipitation and standardized climatic water balance indexes (SPI and SCWBI) identify moisture conditions during the vegetation season in years 1954-1995 in a very similar way, which is confirmed by the evaluation of compliance of these indexes and the value of the correlation coefficient between them.

3. The analysis of relations between the analyzed indexes revealed an inverse relation between SEI and SPI, as well as between SEI and SCWBI. The values of correlation coefficient between SEI and SPI, as well as between SEI and SCWBI, are negative, signifying the decrease trend.

\section{REFERENCES}

1. Abramowitz M., Stegun I.A., 1965. Handbook of mathematical formulas, graphs and mathematical tables. Dover Publications: New York, pp. 1250.

2. Allen R.G., Smith M., Pereira L.S., Pereira A., 1994a. An update for the calculation of reference evapotranspiration. ICID Bulletin, 43(2), 35-92.

3. Allen R.G., Smith M., Pereira A., Pereira L.S., 1994b. An update for the definition of reference evapotranspiration. ICID Bulletin, 43(2), 1-34.

4. Edwards D.C., McKee T.B., 1997. Characteristics of 20 th century drought in the United States at multiple scales. Climatology Report 97-2, Department of Atmospheric Science, Colorado State University, Fort Collins.

5. Gąsiorek E., Grządziel M., Musiał E., Rojek M., 2012. The comparison of standardized precipitation index (SPI) evaluated by gamma and normal distribution for monthly precipitation sums. Infrastruktura i Ekologia Terenów Wiejskich PAN, 3/ III, 197-208.

6. Gąsiorek E., Musiał E., 2014. The comparison of standardized precipitation index (SPI), standardized reference evapotranspiration index (SEI) and standardized climatic water balance (SCWB). Ecological engineering, 39, 155-165.

7. Krishnamoorthy K., Mathew T., Mukherjee S. 2008. Normal-based methods for a Gamma Distribution: prediction and tolerance intervals and stress-strenght reliability. Technometrics, 50(1), 69-78.

8. Łabędzki L., Bąk B., 2004. Standardized climatic water balance as index of drought. Acta Agrophysica, 3(1), 117-124. 
9. Łabędzki L., 2006a. Agricultural droughts. An outline of problems and methods of monitoring and classification. Journal of Water and Land Development. Rozprawy naukowe i monografie, No. 17, pp. 107.

10. Łabędzki L., 2006b. On two methods calculating of meteorological drought index SPI. Mater, XXXVI Seminarium Zastosowań Matematyki, 41-47.

11. McKee T.B., Doesken N.J., Kleist J., 1993. The relationship of drought frequency and duration to time scales. In: Proc. $8^{\text {th }}$ Conf. Applied Climatology, 17-22 January 1993, Anaheim, California, 179-184.

12. McKee T. B., Doesken N, J., Kleist J., 1995. Drought monitoring with multiple time scales, Preprints 9th Conf, Applied Climatology, 15-20 January 1995, Dallas, Texas, 233-236.

13. Mizak K., Pudełko R., Kozyra J., Nieróbca A., Doroszewski A., Świtaj Ł., Łopatka A. 2011. Results of monitoring agricultural drought in winter wheat crops in Poland in the years 2008-2010. WaterEnvironment-Rural areas, t. 11 z. 2(34), 95-107.

14. Radzka E., 2014. Climatic water balance for the vegetation season (according to Iwanow's equation) in central-eastern Poland. Water-Environment-Rural areas, t. 14. z. 1(45), 67-76.

15. Rojek M., 1994. Rozkład przestrzenny klimatycznych bilansów wodnych na terenie Polski w okresie Space distribution of climatic water balance in Poland in the period 1951-1990. Zeszyt Naukowy AR in Wrocław. Inżynieria Środowiska VI, no. 243, 9-21.

16. Thom H.C.S., 1958. A note on the gamma distribution. Monthly Weather Review, 86, 117-122.

17. Thornthwaite C.W., 1948. An approach towards rational classification of climate. Geographical Review, 38, 55-94.

18. Wibig J., 2012. Moisture conditions in Poland in view of the SPEI index. Water-Wnvironment-Rural Areas, t. 12, z. 2(38), 329-340. 